\title{
Phobia And Its Effect On The Academic Achievement Of Physics Students In Imo State, Nigeria
}

\author{
C. N. Ihekwaba, (Ph.D) \\ Department Of Educational/Psychology, \\ Alvan Ikoku Federal College Of Education, \\ Owerri, Imo State, Nigeria. \\ C. C. Nwokocha \\ Department Of Physics, \\ Alvan Ikoku Federal College Of Education, \\ Owerri, Imo State, Nigeria. \\ P. C. Onuike \\ Department Of Physics, \\ Alvan Ikoku Federal College Of Education, \\ Owerri, Imo State, Nigeria.
}

\begin{abstract}
POSTER PRESENTATION MADE AT THE CANADIAN SOCIETY ON THE STUDY OF EDUCATION CONFERENCE HELD FROM $2^{N D}-5^{T H}$ JUNE, 2019 IN UNIVERSITY OF BRITISH COLUMBA, VANCOUVER, CANADA
\end{abstract}

\begin{abstract}
This research studied phobia and its effect on the academic achievement of Senior Secondary School Students of Physics in Owerri Municipal Council Area of Imo State, Nigeria. A sample of 488 students (259 females and 229 males) were taken from four (4) different schools in Owerri Municipal (two co-educational and two noneducational). Data was collected using a Physics Phobia Scale (PPS) developed by the researchers and validated by experts in Measurement and Evaluation from which the phobia levels of the students were ascertained. The students' third term results were also used as secondary data. Using the PPS score and the achievement score, the correlation coefficient, mean, and standard deviation were obtained and T-tests were run for analysis. It was found that a significant negative relationship exist between the students' phobia score and their achievement score. Results also showed that the male students with high phobia performed better than the female students with high phobia and also that the female students had higher phobia than the males; though, the mean difference is however not significant. It is recommended that varying teaching methods and grouping students when teaching will help reduce the phobia level.
\end{abstract}

\section{BACKGROUND TO THE STUDY}

The world we live in on a daily basis depends on discoveries in science for growth and development. Most of the recent technological discoveries are fuelled by breakthroughs in physics research. Advances in technology especially in the present time provide answers about the beginning and the end of the universe; so many landmarks are being made with respect to all spheres of life, ranging from the communication system to the transport system down to teaching and learning using the $21^{\text {st }}$ century strategies. Amazing discoveries are made daily about the interaction of subatomic particles. In spite of these amazing discoveries on the importance of physics to everyday living, it appears that less and less students opt to study 
physics both at the secondary and tertiary education level especially in sub-Saharan Africa to which Nigeria belong.

In times past, most secondary school students take pride in being called science students' especially of physics and Maths combinations. The pride of being seen carrying such big textbooks as principles of physics by Nelkon and other authors was thrilling, the competitive spirit of being the best student among others in science subjects trailed the students study patterns and habits. However, students of the present age take to their heels when the word physics is mentioned. They dread the subject, more so the mathematical operations contained therein. Irrespective of what they think or how they feel, the impact of physics in everyday activities cannot be over emphasized.

Phobia is an extremely strong dislike or fear of someone or something. It is an exaggerated, usually inexplicable and illogical fear of an object, class of objects or situation (http://www.merian-webster.com dictionary/anxiety). It is a type of anxiety disorder defined by persistent fear of an object or situation (American Psychiatric Association, 2013) which typically results in a rapid onset of fear and present for more than six months. APA (2013) opined that the affected person will go to great lengths to avoid the situation or object and if the feared object or situation cannot be avoided, the affected person will have significant distresses. Phobia can be divided into specific phobias, social phobias and Agora phobia (Hamm, 2009).

Specific phobias include fear of certain animals, natural environmental situation, blood, injury or specific situation occasionally triggered by a negative experience with the object or situation.

Social phobia is when the situation is feared as the person is worried about others judging them while Agoraphobia is when fear of a situation occurs because it is felt that escape would not be possible (APA, 2013).

Specific phobias according to APA (2013) affect about 6-8\% of people in the Western world and about 2- 4 of Asian people, Africa, and Latin America in a given year. Social phobia affects about $7 \%$ of the people in the United Stated of America and 0.5 to $2 \%$ of people in the rest of the world while Agoraphobia affects about $1.7 \%$ of people. It is noted that women are affected about twice as often as men. Typically, the onset is around age 10 - 17 that corresponds to secondary school age, the rate becomes lower as people get older and varies among individuals. Phobia for physics is grouped under specific phobia and can imply an unnecessary and overrated fear of the subject.

An analysis in 1984 by the National Center for Education statistics in the United Stated of America (USA) revealed that only $3.9 \%$ of American $9^{\text {th }}$ grade students will continue their education to get a bachelor degree in Science, $0.5 \%$ will go on to get a master degree while only $0.2 \%$ will receive a doctorate degree in a science related discipline. A survey on why secondary school students in the United Kingdom (UK) are not interested in studying physics revealed that students perceive physics as a difficult subject and so are afraid of the subject [William, 0.; Stranisstreet, O., Spall, R.; Boyes, E.; \& Davidson, O. 2003]. Further studies reported that students indicated that they have lower expectations of their ability to accomplish physics tasks [Bamby, 0.; \& Degty, 0. 2006] and that students enter secondary schooling with an equally liking for Biology and physics but over the period of schooling, whereas the liking for Biology remains reasonably stable, their liking for physics declines considerably as they 
perceive Biology as interesting but physics as fearful [Ancell, O.; Gultersrud, O.; Hennksen, 0., \& Isnes, 0. 2004].

In Nigerian secondary schools, the number of students who choose to study physics dwindles as they move to higher classes. Furthermore, in Nigerian universities, physics department and teacher Education Departments in physics continue to witness scarcity of students; most of those who venture to read the course are forced to do so as an alternative to losing admission to higher education. The result is that they perform very poorly and still end up moving to other fields of endeavour after graduation. This has led to shortage of physics teachers in secondary schools. Literature is replete with studies suggesting that students generally regard physics as conceptually difficult, abstract, uninteresting and only suitable for exceptionally talented and gifted students (Erinosho, 2013). Students' difficulty in physics has been attributed to various factors, for instance, a study by Ornek; Robinson; \& Hangan (2008). Identified three factors to include:

i. Factors related to the students that they are capable of controlling.

ii. Factors related to the course and

iii. Factors inherent in the nature of physics.

Another investigation on physics teachers and students in Singapore revealed that teachers held the view that students are prejudiced that physics is difficult whereas students are of the view that the subject is too abstract to understand (Funda, William, Robinson, \& Mark, 2008).

Students have also been found to have difficulty with the nature of the subject requiring special skills in navigating the variety of learning tasks like using equations and formulas, problem solving, theoretical/ conceptual understanding, spatial reasoning and experimentation (Ornek et al., 2008). In agreement students learning difficulty is also associated with the fact that they have to contend with many representations such as experiments, formulae, calculations, graphs, words and conceptual explanations and have to make transformation among them hence increasing the phobia level they have for the subject (Reddish in Erinosho, 2013).

In Nigeria also, the evidence of low enrolment and massive failure in physics, in public examinations like Senior Secondary Certificate Examination (SSCE) and National Examination Council (NECO) is indicative that many students have serious difficulty learning the subject. WAEC examiner's report over the years revealed consistently that on the average, less than $30 \%$ of the total students who registered for SSCE entered for physics. More disturbing is the low level of performance of students where slightly over $30 \%$ of students who sat for the exam passed at the credit level when compared to well over 40\% in Biology and Chemistry (Erinosho, 2013). Some of the reasons adduced for poor learning in physics include students' poor attitude towards the course, lack of motivation for both staff and students, poorly resourced teaching and learning environment, poor mathematical ability, poor teaching methods, Books used, and phobia which is a direct consequence of the other prelisted factors (Ogunleye \& Babajide, 2011). Another study by Karen (2000) in Mallory (2004) opined that students do not choose physics courses because they are admittedly worried about struggling with the class or even failing the class because of the extreme level of difficulty that they associated with physics even when they have not studied the course. Such irrational fears need to be identified and eliminated since students emotional orientation about any subject influence their understanding and learning of that subject (Smith, 2007).

For any positive advancement in physics, and its numerous discoveries, we need a world with more physicists for such advancement; this implies that more students need to be encouraged to study physics both at the secondary and tertiary levels of Education. This can be done by 
identifying what barriers there are, the challenges they have and seek ways of overcoming them and for the fact that physics have been labelled and dreaded as the most conceptually difficult science subject, it is important to explore the underlying emotional difficulties viz-aviz phobia that impedes quality learning of the subject in Imo State, Nigeria.

The purpose of the study specifically ascertained:

1. The proportion of physic students with high and low phobia

2. The mean academic performance score of students with high and low phobia in physics

3. The mean academic performance score of male and female students with high phobia in physics

4. The correlation between the students' academic performance score and their phobia scale score.

The following Research Questions and Hypotheses guided the study

1. What is the proportion of physics students with high and low phobia

2. What is the mean academic performance of students with high and low phobia in physics

3. What is the different in the mean academic performance of male and female physics students with high phobia.

\section{Hypotheses:}

$\mathbf{H O}_{1}$ : There is no significant difference in the mean academic performance of male and female students with high phobia.

$\mathbf{H O}_{2}$ : The index of relationship between the students' academic performance score and phobia scale score is not significant.

\section{METHODS}

The study, a quantitative survey of expost facto research design was carried out in Oweri Municipal Council Area of Imo State, Nigeria using only senior secondary two (SS2) physics students as respondents. The population comprised of four thousand, eight hundred and eighty-eight (4888) SS2 physics students from all the eight public secondary schools in the municipal area from which a sample size of 488 physics students were randomly drawn from four randomly selected school. The instruments for data collection were physics phobia scale (PPS) and the third term (2018) physics result of the sampled students. The PPS was constructed by the researchers' based on experience and purpose of the study. The scale was validated by two experts in tests and measurement for face and content validity. A reliability index of 0.72 was obtained through a pilot study on an equivalent group that is not part of the sample using test-retest approach for ensuing internal consistency of items. The 15 item PPS was rated on a four point modified liket scale of Strongly Agree (SA), Agree (A), Disagree (D) and Strongly Disagree (SD). The total score of each student on the scale was calculated and correlated with their results (the secondary data). 


\section{Research Question 1}

What is the proportion of physics students with high and low phobia?

Table 1: Proportion of physics students with high and low phobia

\begin{tabular}{lccccccc}
\hline $\begin{array}{c}\text { Phobia } \\
\text { Level }\end{array}$ & $\begin{array}{c}\text { No of } \\
\text { students }\end{array}$ & $\begin{array}{c}\text { Number } \\
\text { with high } \\
\text { phobia }\end{array}$ & $\begin{array}{c}\text { Percentage } \\
\text { with high } \\
\text { phobia }\end{array}$ & $\begin{array}{c}\text { Proportion } \\
\text { with high } \\
\text { phobia }\end{array}$ & $\begin{array}{c}\text { Number } \\
\text { with Low } \\
\text { phobia }\end{array}$ & $\begin{array}{c}\text { Percentage } \\
\text { with low } \\
\text { phobia }\end{array}$ & $\begin{array}{c}\text { Proportion } \\
\text { with low } \\
\text { phobia }\end{array}$ \\
\hline Male & 229 & 143 & 29.3 & 0.293 & 86 & 17.6 & 0.176 \\
Female & 259 & 158 & 32.4 & 0.324 & 101 & 20.7 & 0.207 \\
Total & $\mathbf{4 8 8}$ & $\mathbf{3 0 1}$ & $\mathbf{6 1 . 7}$ & $\mathbf{0 . 6 1 7}$ & $\mathbf{1 8 7}$ & $\mathbf{3 8 . 3}$ & $\mathbf{0 . 3 8 3}$ \\
\hline
\end{tabular}

The table above indicates that the number of physics students with high phobia from the sampled 488 students is 301, giving a percentage of 61.7 and a proportion of 0.617 while the number with low phobia is 187, giving a percentage and proportion of 38.3 and 0.383 respectively. The proportion of students with high phobia of 0.617 is much higher than the proportion with low phobia of 0.383. this corroborates Funda, William, Robinson and Mark (2008) report that students are prejudiced that physics is difficult and too abstract to understand. It also supports Erinosho (2013) revelation that students generally regard Physics as difficult, abstract and uninteresting hence the high phobia.

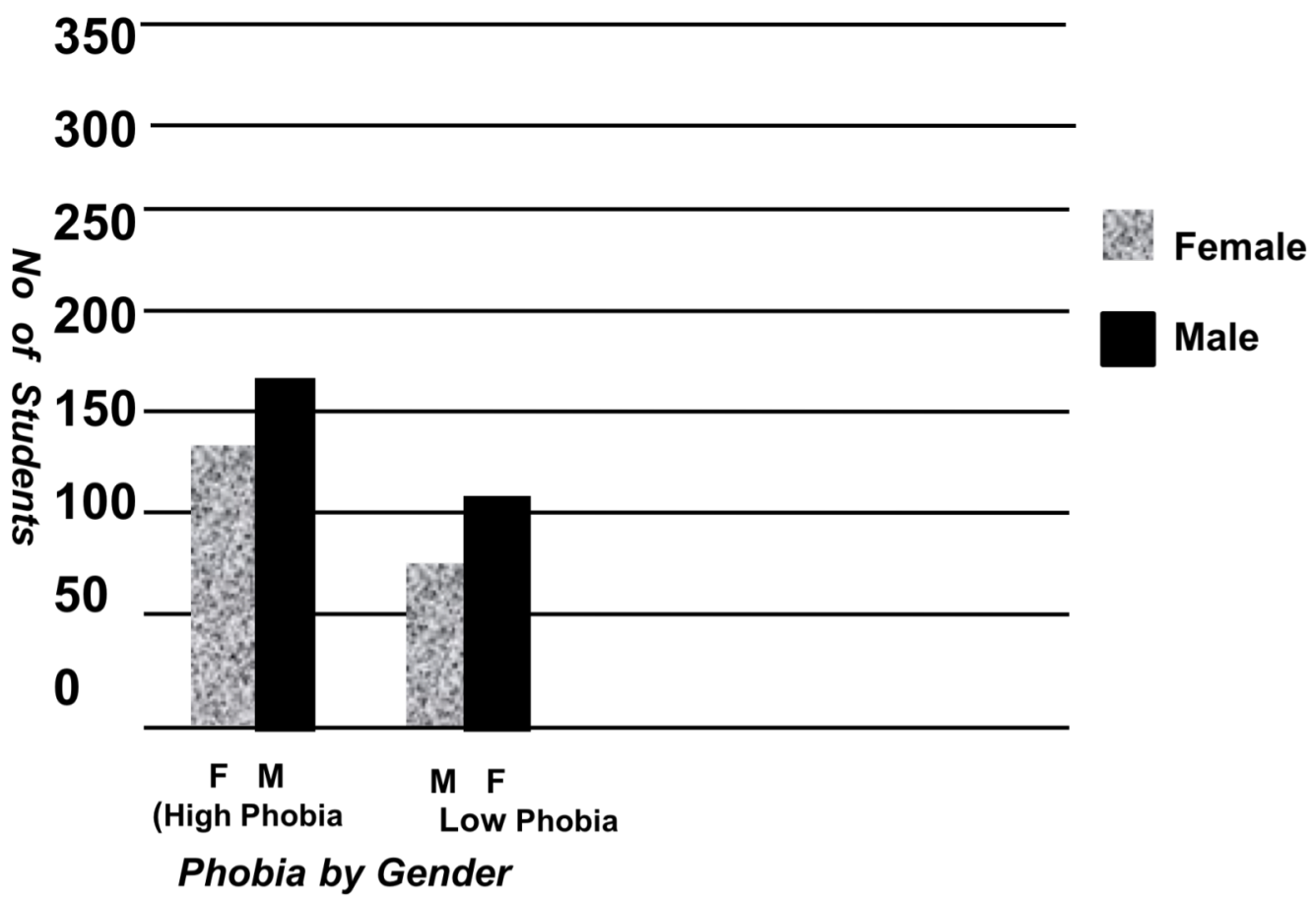

\section{Research Question 2}

What is the mean academic performance of students with high and low phobia in physics?

Table 2: Mean Academic Performance of Students with high and low phobia

\begin{tabular}{cccccc}
\hline Gender & $\begin{array}{c}\text { No of } \\
\text { students }\end{array}$ & Sum of scores & $\begin{array}{c}\text { Mean } \\
\text { Performance }\end{array}$ & $\begin{array}{c}\text { Standard } \\
\text { derivation }\end{array}$ & $\begin{array}{c}\text { Mean } \\
\text { Gain }\end{array}$ \\
\hline Low Phobia & 187 & 11234 & 60.07 & 18.70 & \\
High Phobia & 301 & 13312 & 44.22 & 17.21 & 15.85 \\
\hline
\end{tabular}


Table shows that the general mean score of sampled physics students with low phobia is 60.07 with standard deviation of 18.70 while the mean score of students with high phobia is 44.22 with a standard deviation of 17.21. This gave a mean gain of 15.85 for those with low phobia. Students with low phobia performed better (60.07) i.e above $50 \%$ pass mark than students with low phobia (44.22) i.e below 50\% pass mark.

This finding is supported by Ogunleye and Babajide (2011) assertions that students poor pass performance in physics is due to phobia which is a direct consequence of some other factors. This result is also supported by Pizwan and Nasir (2010) and Bala and Shaaflu (2016) findings that revealed a direct relationship between students' anxiety and solving ability in physics with their academic achievements respectively.

\section{Research Question 3}

What is the difference in the means academic in performance of male and female physics students with high phobia?

Table 3: Difference in the mean academic performance of male and female students' with high phobia

\begin{tabular}{lccccc}
\hline Gender & No of students & Sum of score & Mean X & $\begin{array}{c}\text { Standard } \\
\text { derivation }\end{array}$ & $\begin{array}{c}\text { Mean } \\
\text { Gain }\end{array}$ \\
\hline Male & 143 & 6562 & 45.89 & 17.38 & \\
Female & 158 & 6750 & 42.72 & 16.97 & 3.17 \\
\hline
\end{tabular}

Table 3 shows that the mean score of male physics students with high phobia is 45.89 with a standard deviation of 17.38. This is little a higher than the mean score of the female physics students of 42.72 and standard deviation of 16.97. This gave a mean gain of only 3.17 in favour of the males. Though both the males and females mean score is not up to the $50 \%$ pass mark.

Hypothesis One $\left(\mathbf{H O}_{1}\right)$ : There is no significant difference in the mean academic performance of male and female students' with high phobia

Table 4: t-test of significant difference in the mean performance of male and female physics students' with high phobia

\begin{tabular}{ccccccc}
\hline $\mathbf{n}_{\mathbf{1}}$ & $\mathbf{n}_{\mathbf{2}}$ & $\mathbf{X}_{\mathbf{1}}$ & $\mathbf{X}_{\mathbf{2}}$ & $\mathbf{t}_{\text {cal }}$ & $\mathbf{t}_{\text {table }}$ & Decision \\
\hline 143 & 158 & 45.89 & 47.72 & 0.111 & 1.968 & Do not reject \\
\hline
\end{tabular}

The t-test analysis above revealed that t-calculated value of 0.111 is less than the table $t$-value of 1.968. The stated hypothesis is therefore not rejected. This implies that the stated mean difference of 3.17 (table 3 ) in favour of the males is not significant. This may be so since both males and females performed below pass mark.

Hypothesis Two $\left(\mathbf{H O}_{2}\right)$ : The index of relationship between the students' academic performance score and phobia scale score is not significant

Table 5: Test of significance of index of relationship between students' performance score and phobia scale score

\begin{tabular}{cccccccccc}
\hline $\mathbf{n}$ & $\mathbf{\Sigma x}$ & $\mathbf{\Sigma y}$ & $\mathbf{\Sigma x y}$ & $\boldsymbol{\Sigma} \mathbf{x}^{2}$ & $\mathbf{\Sigma} \mathbf{y}^{2}$ & $\mathbf{r}$ & $\mathbf{T}_{\text {cal }}$ & $\mathbf{T}_{\text {tab }}$ & Decision \\
\hline 488 & 24546 & 16011 & 757596 & 1412604 & 566634 & -0.533 & -13.90 & 1.965 & Reject \\
\hline
\end{tabular}


The table 5 above revealed a negative high index of relationship of -0.533 . This result indicates an inverse proportion in the relationship between the academic score and the phobia score. The t-test analysis of significance at an error level of 0.05 further revealed that the index of 0.533 is significant since the null hypothesis is rejected. The previous works of Bala and Shaafui (2016) also indicated a negative relationship between test anxiety and solving ability skill with students' achievement to support this present study.

The findings of this study revealed as follows;

\section{CONCLUSION}

1. A higher proportion of students has high phobia for physics than the proportion who has low phobia for the subject.

2. Students with low phobia in the subject performed better i.e (above 50\%) than those with high phobia that performed below $50 \%$.

3. The male students with high phobia performed comparably with the female students with high phobia with the males performing a little better. However, the test analysis revealed that the difference in performance between males and females is not significant.

4. There is a negative or inverse index of relationship between the students' academic score and their phobia score. This index was found to be statistically significant.

Phobia at a moderate level may act as a stimulant for good academic performance, but a high level of it induces poor performance among students especially the female students.

\section{SUMMARY/RECOMMENDATION}

1. Teachers should employ multi methods in teaching so as to accommodate all categories of learners

2. Counselors/teachers should identify students with high phobia for counseling and individualized instructions.

3. A stress free and relaxed leaning environment should be provided for all categories of learners in the school to neutralize their initial fears anxieties.

4. Students should be made to collaborate with each other through group work since they learn better through their peers.

5. Female students should be motivated and encouraged more to compete favourable with their male counterparts by providing gender friendly opportunities for them both at home and school.

\section{References}

American Psychiatric Association; (2013), Diagnostic and Statistical Manual of Mental Disorders (5 ${ }^{\text {th }}$ edition) Arlington: American Psychiatric Publishing, pp. 190, 197-202.

Ancell. C; Guttersrud, E; Henriksen \& Isnes, A; (2004). Physics: Frightful, But Fun: Pupils' and Teachers' View of Physics and Physics Teaching, Science Education, 88(5),683-706.

Anxiety; (2012). In Merriam - Webster Online Dictionary. Retrieved on $7^{\text {th }}$ April, 2018 from $\underline{\text { htp: } / / w w w . m e r i a m-}$ webster.com/dictionary/anxiety.

Barmby, P \& Defty, N; (2006). Secondary School Pupils' Perception of Physics. Science Technological Education, 24, pp. 199-215.

Erinosho, S.Y; (2013). How Do Students Perceive the Difficulty of Physics in Secondary School? An Exploratory Study in Nigeria. International journal for Cross- Disciplinary Subjects in Education (IJCDSE), Special Volume 3 Issue 3, 2013.

Funda, O; William, R; Robinson, O \& Mark, P; (2008). What Makes Physics Difficult? International Journal of Environment \& Science Education, Vol.3, Issue 1. 
Hamm, A.0; (2009). Specific Phobias. The Psychiatric Clinics of North America. International Journal of Environment \& Science Education, Vol. 3. Issue 30.

Nasir (2010). Report of significant difference in anxiety levels of males and female physics students which negatively influenced their performance as is also the case for this study with regards to phobia and achievement.

Ogunleye, B.O \& Babajide V.T.F; (2011). Generative Instructional Strategy Enhances Senior Secondary School Students' Achievements in Physics. European Journal of Educational Studies: Vol.3, Issue 3.

Oludipe (2009). In his work revealed that female students exhibited higher test anxiety than their male counterparts.

Ornek, F; Robinson, W.R \& Hangan, M.P; (2008). What Makes Physics Difficult?

Osuala, R.C \& Ihekwaba, C.N; (2014). An Introduction to Research Methods \& Guide to Research Project Reports (2nd Edition). Peacewise Systems Owerri, Imo State.

Smith, K.H; (2000). The Self - Concept and Verbal Academic Achievement of Primary and Secondary Teachers. Unpublished Doctoral Dissertation, University of Melbourne, Australia.

William, C; Stranisstreet, M; Spall, K; Boyes, E; \& Davidson, D; (2003). Why Aren't Secondary School Students Interested in Physics? Physics Education, 38(4), pp. 324- 329. 